\title{
CRACKING IN ZINC LAYERS ON CONTINUOUS GALVANIZED SHEETS A Review
}

\author{
S. LAZIK, C. ESLING and J. WEGRIA* \\ Laboratoire de Métallurgie des Matériaux Polycristallins (LM2P), \\ E.P. CNRS 98, Université de Metz, 57045 Metz, France \\ *Union Minière (UM), Recherche et Développement, Usine des ASTURIES, \\ 59950 Auby les Douai, France
}

(Received 19 November 1994)

\begin{abstract}
The purpose of this paper is to survey the different investigations about cracking behaviour in zinc coatings, due to deformation. Different forming tests have been carried out on electrodeposited and hotdipped zinc coatings. Generally, agreement in the results has been found. The texture gives a good indication about the cracking behaviour of zinc coatings. Thus, texture determination should be performed systematically in examinations relating to the cracking behaviour.
\end{abstract}

KEY WORDS: Zinc coating, cracking, coating failures.

\section{INTRODUCTION}

Zinc based coatings are widely used for corrosion protection of steel-sheet products [Habraken, 1978]. However, there are some significant problems that need to be solved concerning the forming of coated sheet steels. The two most significant problems are those of the coating effect in friction [Hylton et al., 1992], [Hylton, Van Tyne, Matlock, 1993], [Shaffer et al., 1990] and coating damage during forming, depending on the flow and fracture behaviour of the coating material. Characterization of the coating in terms of its microstructure and texture would be a first step in understanding the forming characteristics of coated sheet steels.

The formability of zinc layer is influenced by many factors such as formability behaviour of the substrate, existence of an intermetallic layer between the steel substrate and the zinc coating, zinc texture, grain size of zinc grains, coating hardness, surface roughness as well as quality and quantity of alloying elements in zinc. In particular the texture in the zinc coating influences the forming, due to the anisotropic deformation behaviour of zinc.

This paper gives a review of examinations relating to the cracking behaviour in zinc coatings during forming. First theoretical considerations on deformation behaviour are given. After a short reference to the coating process, the experimental observation of cracking behaviour - especially depending on deformation in pure zinc coatings - will be discussed. 


\section{DEFORMATION MODES OF ZINC}

Slip, twinning, and cracking are the deformation modes to accommodate the strain states in zinc.

The predominant slip mode in zinc is basal slip (0001) along the $<11 \overline{20}>$ directions [Davis and Teghtsoonian, 1963]. The $\{1 \overline{1} 2\}<\overline{1} \overline{1} 23>$ slip system (pyramidal slip) was also observed in zinc [Bell and Cahn, 1957].

Twinning occurs on the $\{10 \overline{1} 2\}$ planes and the twinning shear directions are $\langle 10 \overline{1} \overline{1}\rangle$. For zinc, twinning is favoured by compression parallel and tension normal to the c-axis. Thus, unlike slip, twinning is very dependent on the sense of the stress applied [Partridge, 1967]. One effect of twinning is that grains unfavourably oriented for slip will be reoriented into a more favourable position [Clark and Craig, 1952].

The stress required to activate the deformation modes in hexagonal metals is higly dependent on the orientation of the stress axis and can be described by Schmid's law:

$$
\sigma_{\mathrm{s}}=\sigma_{\mathrm{n}} \cos \varphi \cos \lambda
$$

where $\sigma_{\mathrm{s}}$ denotes the shear stress resolved on the slip or twin system and $\sigma_{\mathrm{n}}$ the applied stress. $\varphi$ is the angle between the stress axis and slip or twin plane normal and $\lambda$ the angle between the stress axis and slip or twinning direction.

If cracking occurs in zinc at a critical stress state, two cracking mechanisms are possible, cleavage and intergranular cracking [Mei and Morris, 1993]. Cleavage in a zinc single crystal was observed to occur exclusively on the basal plane (0001) [Deruyttere and Greenough, 1955-1956], [Gilman, 1955] because of its larger than ideal c/a ratio (1.856>1.633). Intergranular cracking in metals usually results from both grain boundary movement at high temperature and residual element segregation at grain boundaries. At room temperature, grain boundary movement is unlikely during deformation with relatively high speed. Moreover, twin-interface cracking has been observed in hexagonal metals subjected to cyclic stresses [Partridge, 1965].

- Behaviour of a zinc-coated steel sheet under tension stress:

- In the case of prism texture (c-axis parallel to the sheet plane) twinning is impossible for those grains with their c-axis parallel to the tensile axis (shortening of the c-axis), and either cleavage or intergranular cracking will occur. For the extreme case in which the c-axes of all grains are normal to the tensile axis, twinning occurs under tensile stress rather than cleavage.

- In the case of a basal texture (c-axis normal to the sheet plane) twinning or intergranular cracking occurs (cleavage is impossible because the geometrical Schmid factor $\cos \varphi \cos \lambda$ vanishes). As a result of lattice orientation changes caused by twinning, basal slip will be improved. The c-axis, which is normal to the sheet plane in the untwinned crystal, changes in twinned crystal to become almost parallel to the sheet plane that means prismatic texture.

In comparison, a basal-textured coating is more resistant against cracking than a prismtextured one [Mei and Morris, 1993].

- Behaviour of a zinc-coated sheet steel under stamping and friction loads:

- In the case of a prism texture alone twinning cannot occur because it causes elongation along the sheet plane normal. Cleavage is not possible, because the resolved normal stress on the basal plane is zero. If the coating/tool interface is not well lubricated, frictional force can cause cracking. 
- In the case of a basal texture, twinning occurs under stamping, which orientates grains for possible cleavage cracking by the frictional force.

Again, a basal-textured coating is more suitable to resist cracking than a prism-textured one [Mei and Morris, 1993].

When considering the orientation of the c-axis in relation to the stress-axis, it can be stated that:

- cleavages takes place when the c-axis is parallel to the tensile axis;

- twinning occurs when the c-axis is either parallel to the compression axis or normal to the tensile axis;

- neither twinning nor cleavage occurs when the c-axis is normal to the compression axis.

\section{COATING PROCESS}

Commercial production of coated low carbon sheet steels is carried out by either hotdipping or electroplating [Townsend et al., 1986]; [Warnecke et al., 1990]; [Marder, 1990]. Various kinds of zinc coating textures can be produced by various processes and by adjusting the processing parameters such as steel composition, substrate texture, additives in deposition bath, bath temperature, electrodeposition current density, holding time, cooling rate etc. Due to several microstructural and textural characteristics, the coatings show different cracking frequency depending on the coating process.

Different intermetallic phases, which can develop during hot-dip galvanizing, influence the bonding between zinc and steel substrate and the subsequent deformation behaviour. The phases are indicated on the iron-zinc phase diagram (Figure 1). The

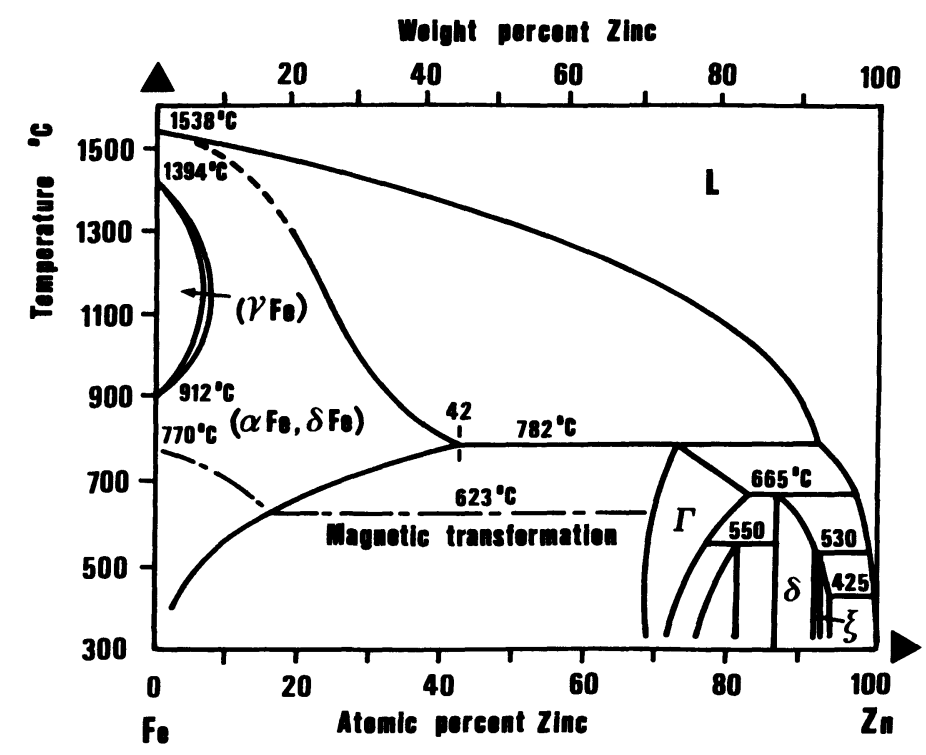

Figure 1 Fe-Zn equilibrium phase diagram [Kubaschewski, 1986]. 
$\alpha$ phase is a solid solution of zinc in iron. The intermetallic phase located closest to the iron substrate is the $\Gamma$ phase (75at.\% $\mathrm{Zn}, 25 \mathrm{at} . \% \mathrm{Fe}$ ). The $\delta$ phase (90at.\% $\mathrm{Zn}$, 10.at\% Fe) is next to develop, followed by the $\zeta$ phase ( 94 at. $\% \mathrm{Zn}, 6$ at. $\% \mathrm{Fe}$ ) [Cameron, Harvey, Ormay, 1965]. The last phase found on the surface of the coating is the $\eta$ phase (solid solution of iron in zinc) which solidifies as a cast dentritic structure (Table 1) [Marder, 1990].

Table 1 Zn-Fe phases, by [Marder, 1990].

\begin{tabular}{ccc}
\hline Phase & Formula & Crystal structure \\
\hline$\eta$ & $\mathrm{Zn}(\mathrm{Fe})$ & hcp \\
$\zeta$ & $\mathrm{FeZn}_{13}$ & monoclinic \\
$\delta$ & $\mathrm{FeZn}_{7}$ & hexagonal \\
$\Gamma_{1}$ & $\mathrm{FeZn}_{4}$ & fcc \\
$\Gamma$ & $\mathrm{Fe}_{3} \mathrm{Zn}_{10}$ & bcc \\
$\alpha$ & $\mathrm{Fe}(\mathrm{Zn})$ & bcc \\
\hline
\end{tabular}

The thickness of the intermetallic phases depends on the diffusion of iron into the zinc coating and is a function of bath temperature, dip time, as well as of alloying elements.

In several cases, a few microcracks have been found in hot-dip coatings right after the processing [Makimatilla, Ranta-Eskola, 1984], [Deits, 1990]. It has been reported that hot dip coating cracks may nucleate from cracks observed in the relatively brittle zinc-iron interface [Stevenson, 1985], [Gronostajski and Ali, 1988]. It has been recognized that powdering resistance decreases with the increase of $\mathrm{Fe}$ content within coating layer. Nevertheless, there is no unanimous agreement yet about which intermetallic phase $-\delta$ or $\Gamma$ - causes powdering. However, Chang (1990) has shown that the $\delta$ phase is responsible for the loss of coating during deformation. Measurements of hardness and total crack length have confirmed, that the $\delta$ phase is the harder one [Foct, lost, Reumont, 1993].

A major orientation of hot dipped zinc is $\{0001\}<u v t w>$ and a minor one $\{10 \overline{1} 0\}<0001>$ for minimized spangle [Takechi et al., 1981]. But further investigation [Vlad, Dahms and Bunge, 1988] has shown that a (0001) fibre texture in the zinc phase of galfan- and hot-dip galvanized sheet steels is formed when no alloy layer exists between the iron and the zinc. The formation of an alloy layer between the zinc and the iron seems to be favoured by the presence of the (113)[11i0] and (557)[110] texture components at the expense of the $\{111\}<110>$ texture component. A strong texture component $<111>$ parallel to the normal direction will induce a larger zinc volume (0001) parallel to the sheet surface.

The electrogalvanizing process is conducted at a temperature close to room temperature. Intermetallic layers are not produced in the coating. A bond is formed between the $\mathrm{Fe}$ and $\mathrm{Zn}$ by sharing electrons at the interface [Rangarajan, 1989]. In commercial electrogalvanized sheet steels the texture of the zinc grains has a relationship to the iron substrate texture because of the interfacial lattice coincidence between zinc and iron crystals, as can be seen in Figure 2. The closest packed planes and directions of both lattices, the $\{110\}<111>$ for iron and the $\{0001\}<1120>$ for zinc, are nearly in coincidence. Takechi et al. (1981) have found that substrates with a higher Lankford coefficient (i.e. higher concentration of $\{111\}$ planes parallel to the sheet surface) induce 


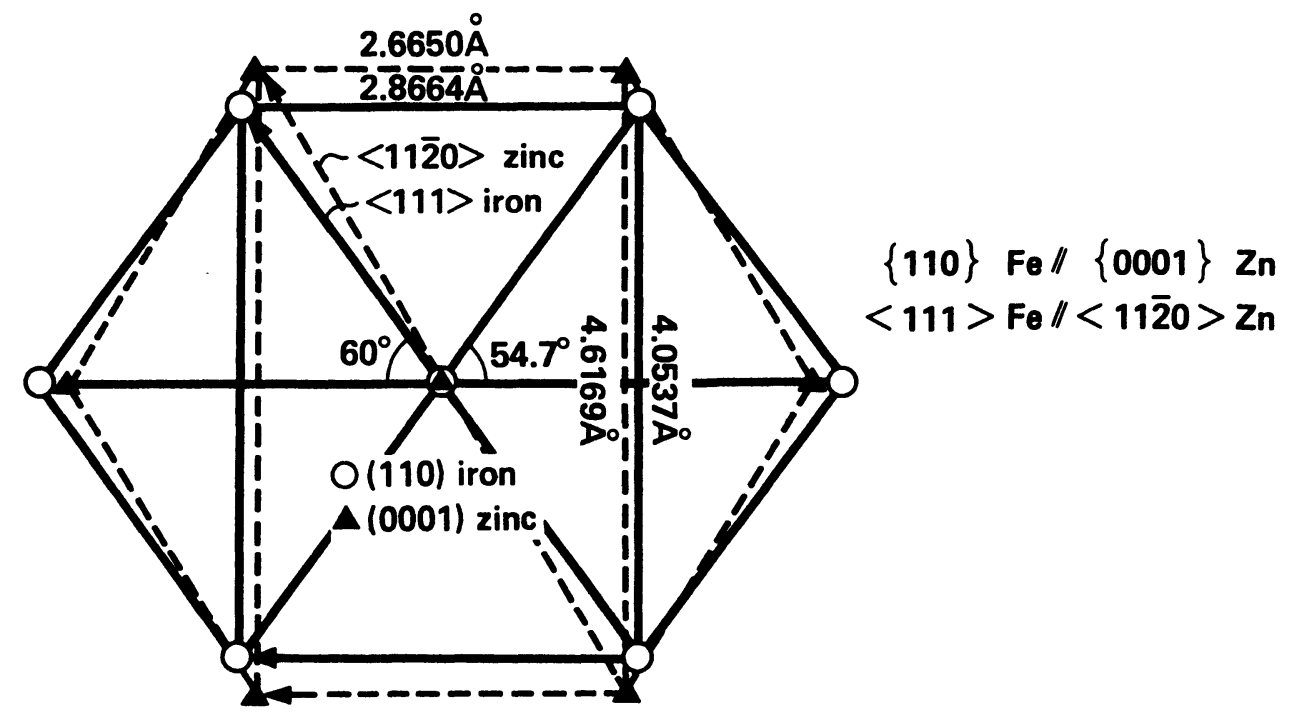

Figure 2 Interfacial lattice coincidence between zinc and iron crystals [Takechi et al., 1981].

a $\{10 \overline{1} 3\}<11 \overline{2} 0>$ main orientation in the zinc. By decreasing Lankford coefficient the $\{10 \overline{1} 3\}$ preferred planes shift to $\{0001\}$, which is very commonly found in the case of coatings on amorphous iron substrate. A $\{100\}$ texture in cold rolled steel favoured a $\{11 \overline{2} 0\}$ texture in the coating [Lindborg, 1975].

\section{EXPERIMENTAL OBSERVATION}

\section{Deformation behaviour of zinc coatings}

Two commercial zinc electrodeposits were studied before and after $25 \%$ uniform tensile elongation by [Shaffer, Morris, Wenk, 1990]. The first coating (Figure 3a) shows very little changes in texture after deformation, while the second one in $3 \mathrm{~b}$ exhibits changes of the basal planes, both towards sheet normal (moved towards center) and away from tensile axis. SEM studies have shown that in the first coating with the majority of basal planes 55 to 75 degree inclined from the sheet plane, straining was primarily accommodated by intergranular cracking. In the second coating, slip and rotation of grains result in a change of texture.

Pak, Lin and Meshii (1989) found cracking in commercial coatings exhibiting a majority of basal planes nearly perpendicular ( 85 degrees or more) to the sheet plane. Little cracking has been found in coatings with pyramidal orientations (basal planes 40 to 70 degrees to the sheet).

Nine commercial pure zinc electrogalvanized steel sheets (coating weight between $40 / 40$ to $90 / 90 \mathrm{~g} / \mathrm{m}^{2}$ ) were studied with three testing methods, axisymmetric stretch forming test, the drawbead test, and the tensile test, in the work by Pak and Meshii (1990a). Two classes of deformation behaviour, cracking and non cracking, were found 

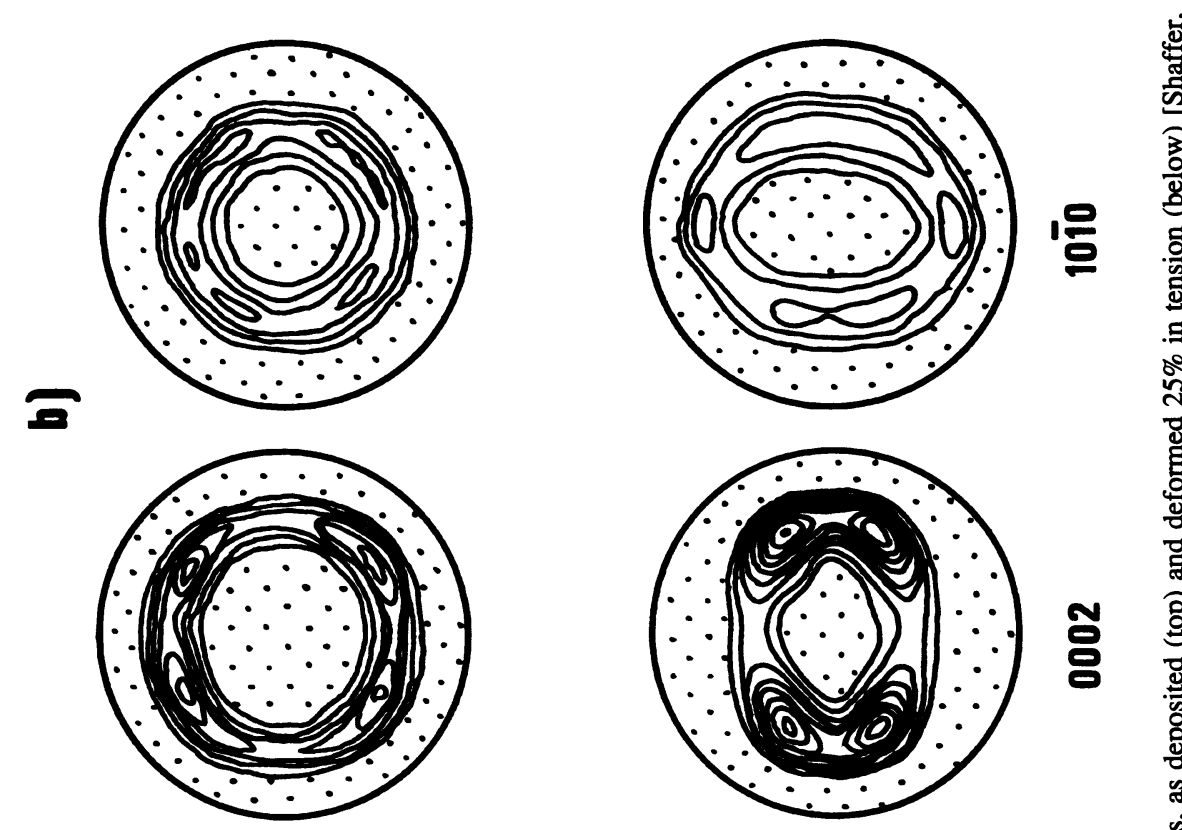

है
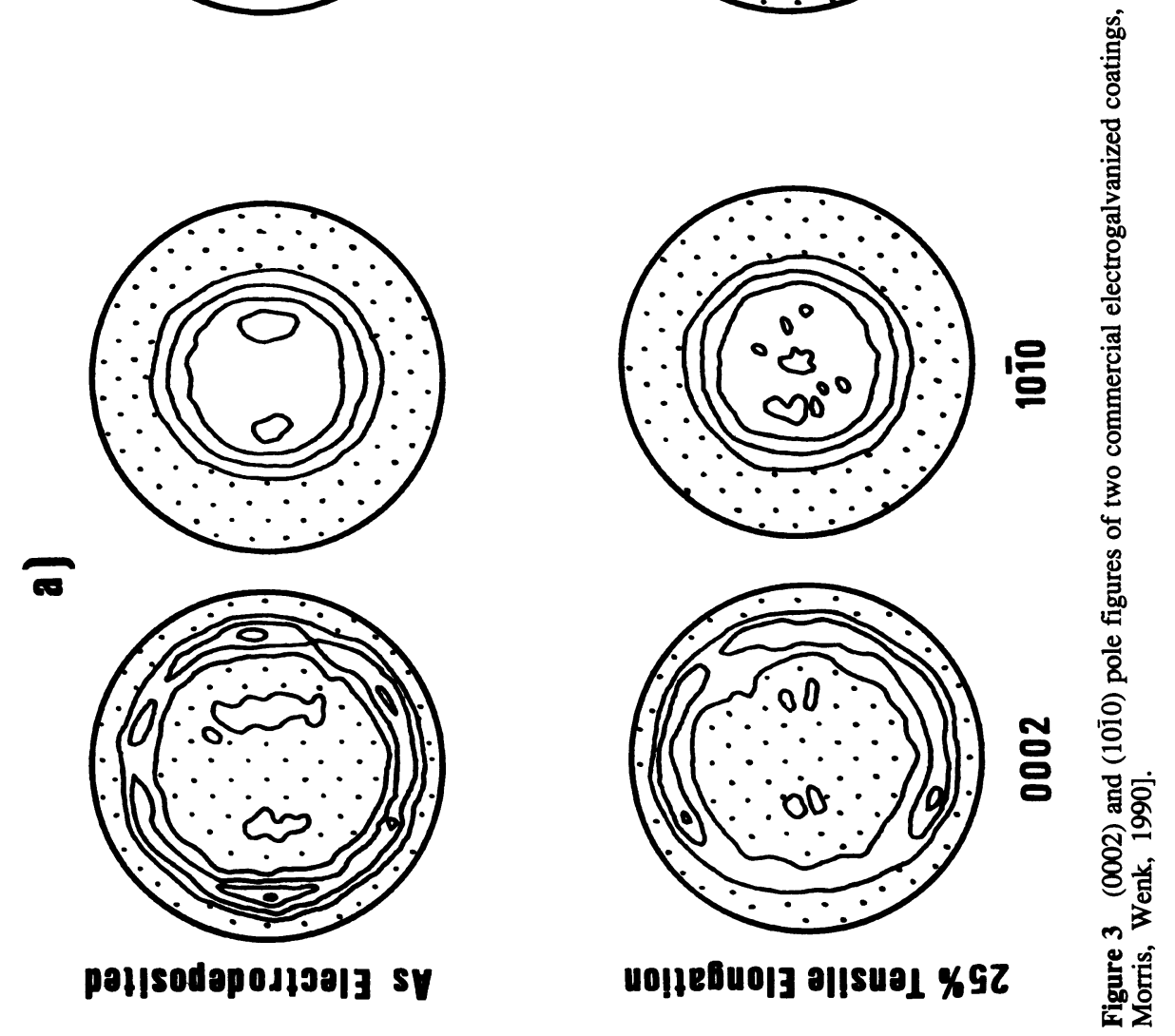
independent of the testing method. Figure 4 shows the intensity as a function of the basal plane inclination angle before (a) and after (b) tensile deformation. The noncracking specimens have a maximum intensity around $30^{\circ}$, which is shifted to the left after deformation and becomes flat, indicating that the basal planes tilt further in the tensile direction due to shear strain. The maximum for the cracking specimens was around $90^{\circ}$ and changed only little after deformation. That means that less plastic deformation takes place in the cracking specimens. The cracking group showed a prism texture (zinc basal plane largely perpendicular to the substrate, $(1120)$ is the surface plane) and the non cracking group a pyramidal texture (zinc basal plane about $30^{\circ}$ to the substrate, (1013) is the surface plane).

Nevertheless, Aoki, Horita and Herai (1982) stated that a change in strain path has a greater influence on the separation of the coating from the substrate than does a single strain state. Compared to a single state (the flange of partially drawn cups) the separation of the coating from the substrate has shown to be greater after a change in strain state (fully drawn cups).

Laboratory deep drawing tests were investigated on three electrogalvanized pure zinc coatings (coating weights between 60 to $70 \mathrm{~g} / \mathrm{m}^{2}$ ) in the work by Deits and Matlock (1990). The coatings with favorable (1013) orientations parallel to the sheet surface accommodated plastic deformation by slip, related to an orientation shift to (0001). The coating with unfavorable (1011) orientations has cracked to accommodate substrate deformation perpendicular to the maximum tensile stress without plastic deformation. The microstructure of the coating between the cracks was left relatively undeformed and almost identical to that observed in the as-received condition.

Uniaxial tensile tests (strain rate $0.25 / \mathrm{min}$ ) were investigated on three electrogalvanized coatings (coating weights 30,70 and $100 \mathrm{~g} / \mathrm{m}^{2}$ ) called EG30, EG70 and EG100 respectively by Rangarajan et al. [1989]. The coatings have grains with $\{11 \overline{2} 2\}$ surface planes, which were favorable for basal plane slip. In Figure 5 the texture changes due to deformation were monitored. The strong $\{11 \overline{2} 2\}$ texture, especially on the surfaces of the heavier coatings (EG100 and EG70), disappears and the $\{10 \overline{1} 1\}$ texture stabilizes with strain. Figure $5 b$ shows that the deviation factor of $\{0002\}$ becomes more negative with increasing strain in the heavier coatings, while EG30 shows no change. The ability to accommodate strain by plastic flow prevented cracking in the electrogalvanized coatings and ensured good substrate coverage, except in the thinnest coating at high strains.

Draw-bead test, tensile test, V-shaped bending test and drawing test were used to study the correlation of peeling-off behaviour and press formability of electrogalvanized steel sheets (coating weight between 10 to $40 \mathrm{~g} / \mathrm{m}^{2}$ ) [Hisamoto et al., 1990]. Peelingoff is caused by internal cracks and deformation of the coating due to compressive stress during forming. After the drawing test without compressive stress component, no peeling-off was observed. Futhermore it was found that the coating hardness, especially corresponding to an increase in coating weight of more than $20 \mathrm{~g} / \mathrm{m}^{2}$, contributed most to its peeling-off behaviour. The difference in hardness can probably be due to a difference in texture in the pure zinc coatings. An improvement of cracking behaviour was made with double layered coatings, which have the ability of mitigating compressive stress during forming in their components [Hisamoto et al., 1990].

Bending under tension tests of eight pure zinc laboratory electrogalvanized coated sheet steels (coating weights from 20 to $100 \mathrm{~g} / \mathrm{m}^{2}$ ) with different textures was carried out to examine the dependence of deformation behaviour on texture, surface morphology and grain size [Wenzloff, Van Tyne, Matlock, 1993]. Only the coatings with prism 


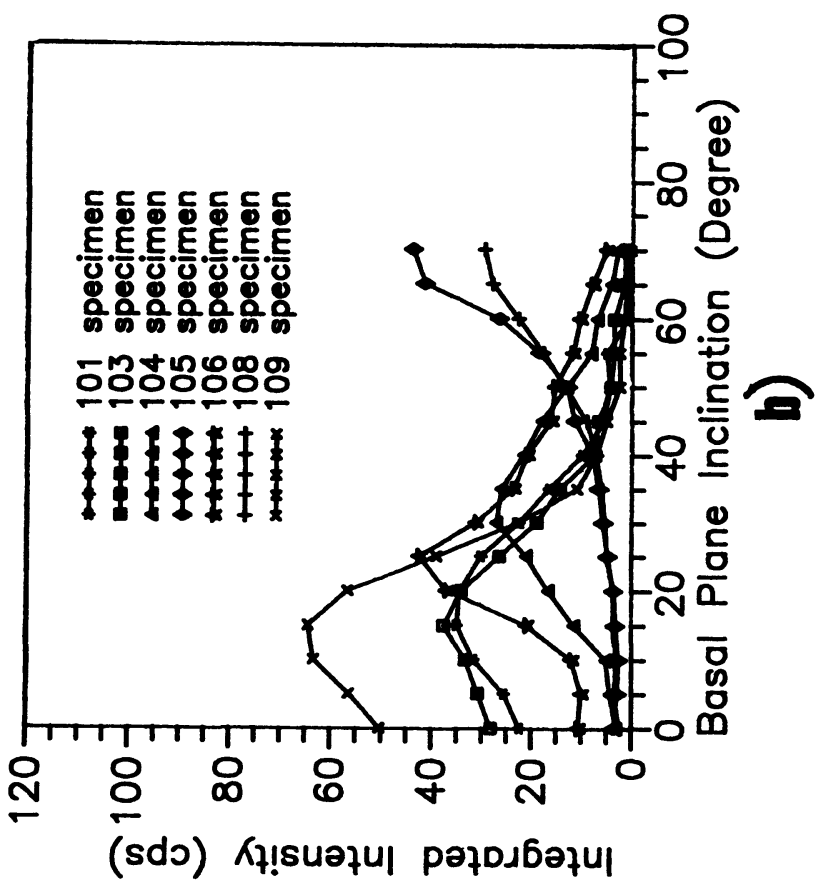

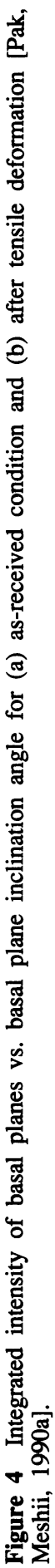

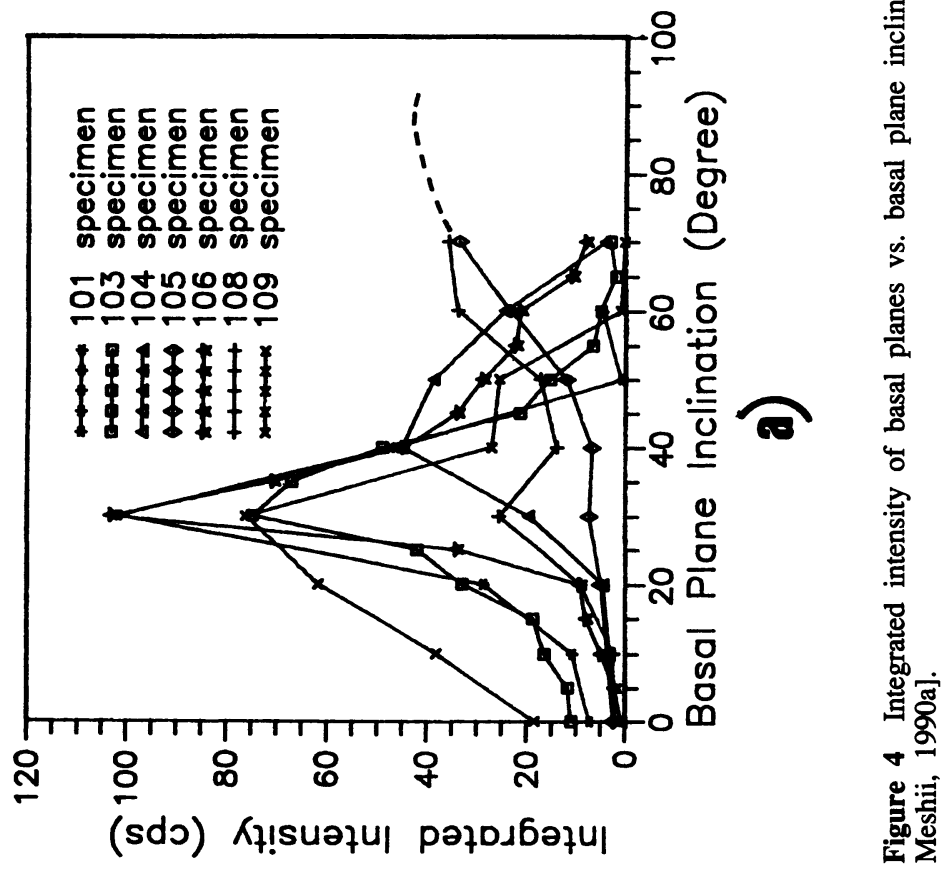



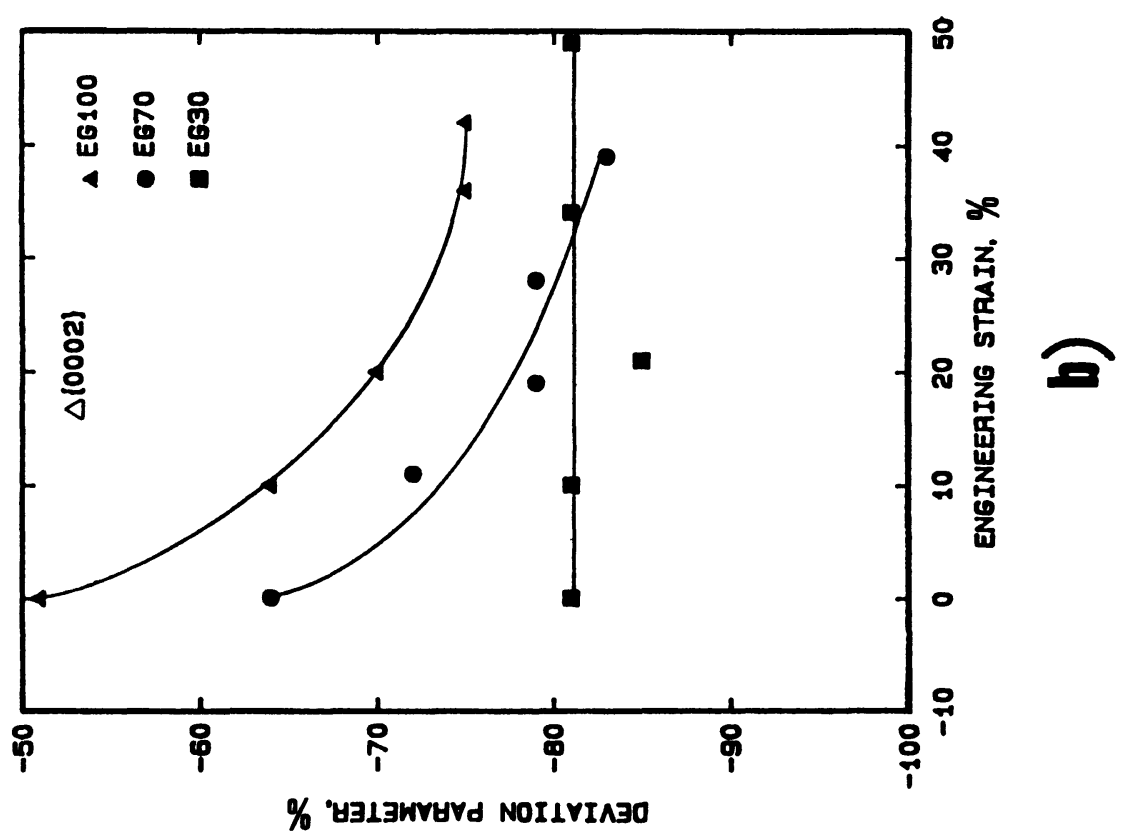

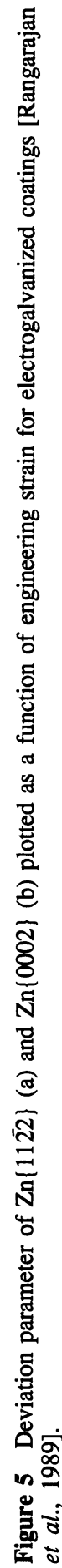

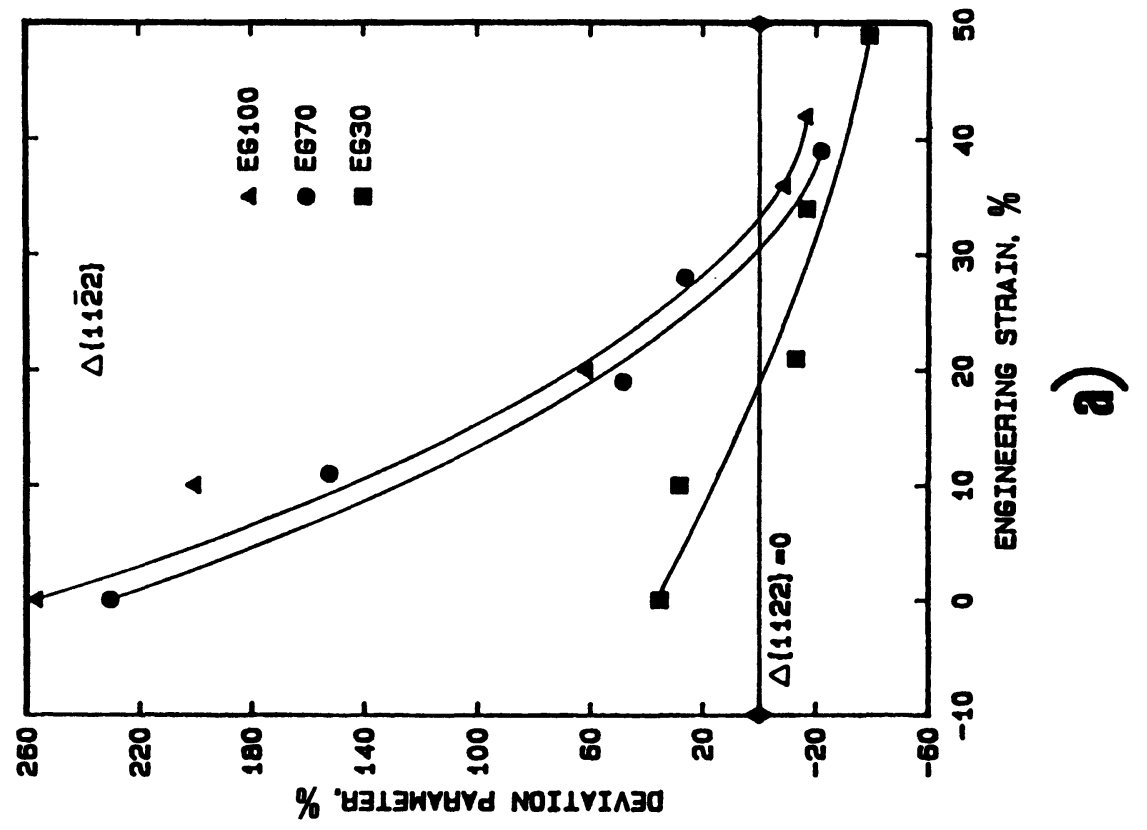


texture cracked, whereas the coatings with pyramidal textures showed large deformation regions after the test.

Three different hot-dip galvanized sheets were submitted to a complex roll forming operation, which induces tensile strains, in the work by Rangarajan et al. [1990]. Due to different spangle sizes and textures, the coatings showed different cracking characteristics by deformation. The coating with relatively large spangle size and a moderate basal plane texture accommodates strain by a combination of plastic flow and cracking. Due to slip, the crack faces showed little separation. The second coating with comparable spangle size but strong basal plane texture accommodated strain primarily by the development of large, wide cracks with limited associated plastic flow. The third coating with the smallest spangle size and dominant basal plane texture, exhibited extensive fine cracking. The crack widths were smaller than in the second sample [Rangarajan et al., 1990].

Laboratory deep drawing at hot-dip galvanized sheets [Deits, 1990] showed a few cracks with aluminium-rich inclusions. However, the cracking adjacent to the inclusions is oriented perpendicular to the radial direction or maximum tensile stress. Inclusions have been shown to be sites of crack initiation where decohesion of the particle and matrix occurs [Gronostajski and Ali, 1988].

Cracking in zinc coatings may depend not only on the overall texture with respect to macroscopic stress or strain state, but also on the local grain misorientation, and the inherent grain boundary strength. Even at favorable inclinations to the sheet plane, cracking could be expected for clusters of grains whose basal planes were oriented parallel to the loading direction [Shaffer, Morris, Wenk, 1990]. Such groups of grains would have zero resolved shear stress on the basal slip system, thus strain accommodation of these regions would have to be achieved through cracking. However, since twinning in zinc may be expected to occur for such grains under tension parallel to the basal planes, it is also possible that the deposition conditions of this particular coating led to inherently weak grain boundaries. Therefore, local texture measurements of grain misorientations across the fracture boundaries via TEM may be necessary to answer these questions.

The effect of grain size on cracking behaviour was found to be secondary to that of texture although larger grains tend to promote some cracking [Pak and Meshii, 1990a].

The previously described observations of deformation of zinc coated steel sheets have been summarized in Table 2 .

With electrogalvanized sheets, it can be seen that cracking occurs for inclinations of basal plane larger than $65^{\circ}$ to the sheet surface. For inclinations lower than $65^{\circ}$ plastic deformation in the coating prevents cracking. These results were obtained after different deformation tests. The different cracking behaviour at an inclination of the basal plane of $65^{\circ}$ could be due to the different applicated deformation tests. Therefore, an inclination of about $65^{\circ}$ seems to constitute a borderline case.

Generally a basal plane texture exists in hot dip coatings. Cracking was found in all cases described after different deformation tests. Microstructural investigations have shown that this is especially due to cracking in the brittle intermetallic.

Nevertheless, as can be seen in Table 2, tests were examined on various ways and are not always comparable with each other. For a better comparison of results, it would be necessary to have similar experimental procedure tests. In particular texture investigations should be introduced into observation programs. Futhermore, microstructural characterisations may be useful. 
Table 2 Results of observations.

\begin{tabular}{|c|c|c|c|c|c|}
\hline $\begin{array}{c}\text { Coating } \\
\text { type }\end{array}$ & $\begin{array}{l}\text { Surface } \\
\text { plane }\end{array}$ & $\begin{array}{l}\text { Inclination of } \\
\text { basal plane } \\
\text { to sheet } \\
\text { surface }\left[{ }^{\circ}\right]\end{array}$ & $\begin{array}{c}\text { Defomation } \\
\text { test }\end{array}$ & $\begin{array}{l}\text { Deformation } \\
\text { behaviour }\end{array}$ & Reference \\
\hline Electrogalv. & $\begin{array}{l}(10 \overline{1} 0)+ \\
(1120)\end{array}$ & 90 & $\begin{array}{l}\text { axisymmetric stretch } \\
\text { forming test, } \\
\text { drawbead test, } \\
\text { tensile test } \\
\text { bending under tension } \\
\text { friction test }\end{array}$ & cracking & $\begin{array}{l}\text { Pak and Meshii } \\
\text { (1990a) } \\
\text { Wenzloff, Van Tyne } \\
\text { Matlock (1993) }\end{array}$ \\
\hline Electrogalv. & & 75 & tensile test & $\begin{array}{l}\text { intergranular } \\
\text { cracking }\end{array}$ & $\begin{array}{l}\text { Shaffer, Morris, } \\
\text { Wenk (1990) }\end{array}$ \\
\hline Electrogalv. & (101̄1) & 65 & $\begin{array}{l}\text { laboratory deep } \\
\text { drawing } \\
\text { (tensile stress) }\end{array}$ & cracking & $\begin{array}{l}\text { Deits (1990) } \\
\text { Deits and } \\
\text { Matlock, (1990) }\end{array}$ \\
\hline Electrogalv. & & 65 & tensile test & slip & $\begin{array}{l}\text { Shaffer, Morris, } \\
\text { Wenk (1990) }\end{array}$ \\
\hline Electrogalv. & $\{1122\}$ & 60 & $\begin{array}{l}\text { uniaxial tensile tests } \\
\text { bending under } \\
\text { tension friction test }\end{array}$ & $\begin{array}{l}\text { slip } \\
\text { plastic flow }\end{array}$ & $\begin{array}{l}\text { Rangarajan et al. } \\
\text { (1989) } \\
\text { Wenzloff, Van Tyne } \\
\text { Matlock (1993) }\end{array}$ \\
\hline Electrogalv. & $(1013)$ & 35 & $\begin{array}{l}\text { axisymmetric stretch } \\
\text { forming test, drawbead } \\
\text { test, tensile test } \\
\text { laboratory deep } \\
\text { drawing (tensile stress) } \\
\text { bending under tension } \\
\text { friction test } \\
\text { bending under tension } \\
\text { strip drawing test } \\
\text { (friction stress) } \\
\text { deep drawing }\end{array}$ & slip & $\begin{array}{l}\text { Pak and Meshii } \\
\text { (1990a) } \\
\text { Deits (1990) } \\
\text { Wenzloff, Van Tyne, } \\
\text { Matlock (1993) } \\
\text { Rangarajan, } \\
\text { Matlock and Krauss } \\
\text { (1990) } \\
\text { Deits and } \\
\text { Matlock, (1990) }\end{array}$ \\
\hline Eletrogalv. & $\begin{array}{l}(1013)+ \\
(1120)\end{array}$ & $35+90$ & $\begin{array}{l}\text { bending under tension } \\
\text { friction test }\end{array}$ & plastic flow & $\begin{array}{l}\text { Wenzloff, Van Tyne, } \\
\text { Matlock (1993) }\end{array}$ \\
\hline Hot-dip & $(0002)$ & 0 & $\begin{array}{l}\text { bending under tension } \\
\text { strip drawing test } \\
\text { (friction stress) }\end{array}$ & cracking & $\begin{array}{l}\text { Rangarajan, } \\
\text { Matlock and } \\
\text { Krauss (1990) }\end{array}$ \\
\hline \multirow[t]{2}{*}{ Hot dip } & $\begin{array}{l}\text { moderate } \\
(0002) \\
\text { texture }\end{array}$ & 0 & $\begin{array}{l}\text { complex roll forming } \\
\text { (tensile strain) }\end{array}$ & $\begin{array}{l}\text { plastic flow } \\
\text { and cracking }\end{array}$ & $\begin{array}{l}\text { Rangarajan et al. } \\
\text { (1990) }\end{array}$ \\
\hline & $\begin{array}{l}\text { strong } \\
(0002) \\
\text { texture }\end{array}$ & 0 & & cracking & \\
\hline Hot-dip & & - & $\begin{array}{l}\text { laboratory deep } \\
\text { drawing } \\
\text { (tensile stress) }\end{array}$ & $\begin{array}{l}\text { cracking } \\
\text { without and } \\
\text { with } \mathrm{Al}-\text {-rich } \\
\text { inclusions }\end{array}$ & Deits (1990) \\
\hline
\end{tabular}




\section{Alloy elements}

Research in the past few years has shown that $\mathrm{Zn}$-alloy coatings perform better in atmospheric corrosion tests than pure zinc. The predominant hot dip zinc-alloy coatings include the galvannealed coating which is made up of $\mathrm{Zn}$-Fe alloys [Shi et al., 1990] as well as Galfan $(5 \% \mathrm{Al})$ and Galvalume $(50 \% \mathrm{Al})$ coatings - which are $\mathrm{Zn}$ - $\mathrm{Al}$ alloy coatings [Dreulle et al., 1985] of various compositions. As in the case of hot dip coatings, they are electroplated $\mathrm{Zn}$-alloy coatings.

Makimatilla and Ranta-Eskola (1984) have shown that the Galvalume and Galfan coatings perform better than pure zinc hot dip coatings under biaxial stretching. Therefore, texture changes should been studied under tests simulating industrial conditions.

In electrodeposited heat treated iron-zinc alloys (11 and 18 wt.\% iron) cracks have occured along the coating, so that the coating appears very blocky [Drewien, Ackland, Marder, 1990]. When heated to temperatures of $300^{\circ} \mathrm{C}$ or more the coatings show cracks perpendicular to the coating/substrate interface. A slower cooling rate helps maintain the coatings integrity, but cracking still occurs. It has been found that cracks are associated with asperities and grain boundaries in the substrate. Similar observations have been made in the work by Deits and Matlock (1990). The cracks in the substrate were shown to be a consequence of the galvannealing process on the integrity of ferrite grain boundaries. Gupta, Cline and Patil (1984) have stated that microcracks in the coating caused propagation of cracks into the substrate at ferrite grain boundaries with increasing strain. Substantial diffusion of zinc in iron had occurred especially at the grain boundaries. The chemical composition of substrate may influence the diffusion of zinc to the ferrite grain boundaries as was indicated by Allegra, Hart and Townsend (1983). This would influence the deformation behaviour of the substrate.

Beside the above mentioned $\mathrm{Zn}$-alloys there are alloying elements in a small quantity which may influence the forming and corrosion behaviour of the zinc coatings. The metals co-deposited with zinc may include iron, nickel, chromium, cobalt and molybdenum, either singly or in combination [Rangarajan, 1989]. Alloying elements in the steel substrate may influence the forming of hot dipped coatings. A small content of $\mathrm{Si}$ in the iron substrate influences the thickness of the intermetallic layer, especially the $\zeta$-phase, and causes the so-called Sandelin effect. That means that, at a $\mathrm{Si}$ concentration of about $0.07 \mathrm{wt} \%$, the coating may be several times thicker [Foct, Reumont, Perrot, 1993]. C and P in the steel substrate delay the alloying reaction between zinc and iron while $\mathrm{Ti}$ and $\mathrm{Ni}$ promote it [Lin, Chiou and Meshii, 1993]. Al in the $\mathrm{Zn}$-bath moderates the alloying in the interphase by forming an $\mathrm{Fe}-\mathrm{Al}$ or $\mathrm{Fe}-\mathrm{Al}-\mathrm{Zn}$ intermetallic compound at the beginning of galvanizing a so-called inhibition layer [Lin, Chiou, Meshii, 1993] and contributes to limiting the growth of the intermetallic layer [Hughes, 1951], [Bablik, 1950], [Haughton, 1953]. At an Al-content of 0.144\% in the Zn-bath and a immersion time less than 30s the thickness of the inhibition layer became thin, and discrete distributed $\zeta$ crystallites exist in the interface [Tang, Adams, 1993]. The addition of the Antimony, especially in electrogalvanized coatings, produces a smoother surface [Wenzloff, Van Tyne, Matlock, 1993]. A prismatic texture formed by addition of $\mathrm{Cd}$ causes low friction coefficient but an increased tendency to cracking in the Zn-coating [Shaffer et al., 1990].

The size of the spangles influences the fracture behaviour of coatings. A small spangle size is preferred in many applications. The addition of lead, tin and cadmium are made to the zinc bath to control the spangle size. A low $\mathrm{Pb}$ content in the bath promotes minimum spangle or spangle free appearance. The presence of aluminium decreases the spangle size. An addition of antimony increases spangle density and improves the 
quality, lustre and uniformity of the coating [Rangarajan, 1989], [Deits, 1990].

The difference in the type of cracking observed indicates that by controlling the orientation of the solidification structure, intraspangular cracking may be avoided. To reduce the interspangular cracking, the cleanliness of the solidifying zinc would be important to reduce alloy segregation at spangle boundaries and thus limit crack nucleation sites [Deits, 1990].

\section{MODELS OF CRACK FORMING}

Various models depicting the deformation characteristics of the coatings were presented by Deits and Matlock, (1990). The substrate is assumed to deform isotropically and the zinc coating anisotropically.

Cracking due to tensile stress is illustrated by the model in Figure 6. Stage 1 shows the stresses developing in the coating to accommodate tensile strains applied in the substrate, transferring a tensile stress concentration to the coating through shear stresses at the coating/substrate interface. When a critical stress state is obtained at the interface, the coating cracks, and the crack propagates towards the surface (stage 2). Since the tensile stresses in the coating have been relieved by cracking, the coating acts as an

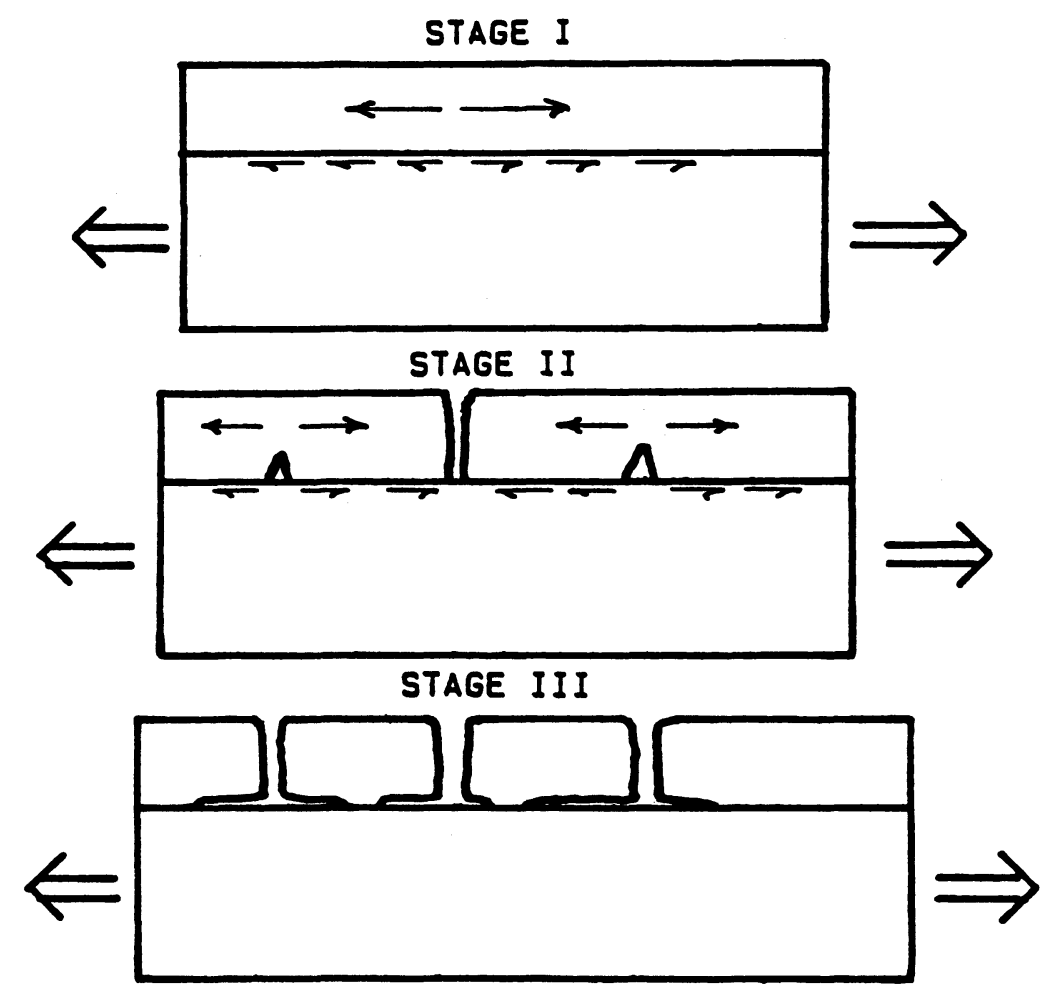

Figure 6 Three-stage schematic drawing showing the steps leading to coating cracking due to imposed tensile strains [Deits, 1990]. 
elastic body and provides enough rigidity to withstand the shear stresses applied at the coating/substrate interface. As tensile deformation continues the shear stresses applied at the interface reach a critical value causing separation between the coating and substrate followed by relieving of stresses. Only a small region that remains attached to the substrate is not influenced by the shear stresses and will not completely separate from the substrate (stage 3).

A mechanism for denting/cracking of Galfan during solidification is schematically illustrated in Figure 7 [Bluni and Marder, 1993]. Due to a shortage of liquid between adjacent growing eutectic nodules which causes a surface depression and a segregation of impurities such as $\mathrm{Pb}(\mathrm{t} 1)$ the grain boundary areas should be weak and impure in comparison to the bulk coating. When solidification and cooling stresses are induced (t2), cracking will occur within these grain boundaries ( $t 3)$. This so-called denting is associated with subsequent cracking during deformation.

An analytical method to calculate the stress distributions and microcracking behaviour
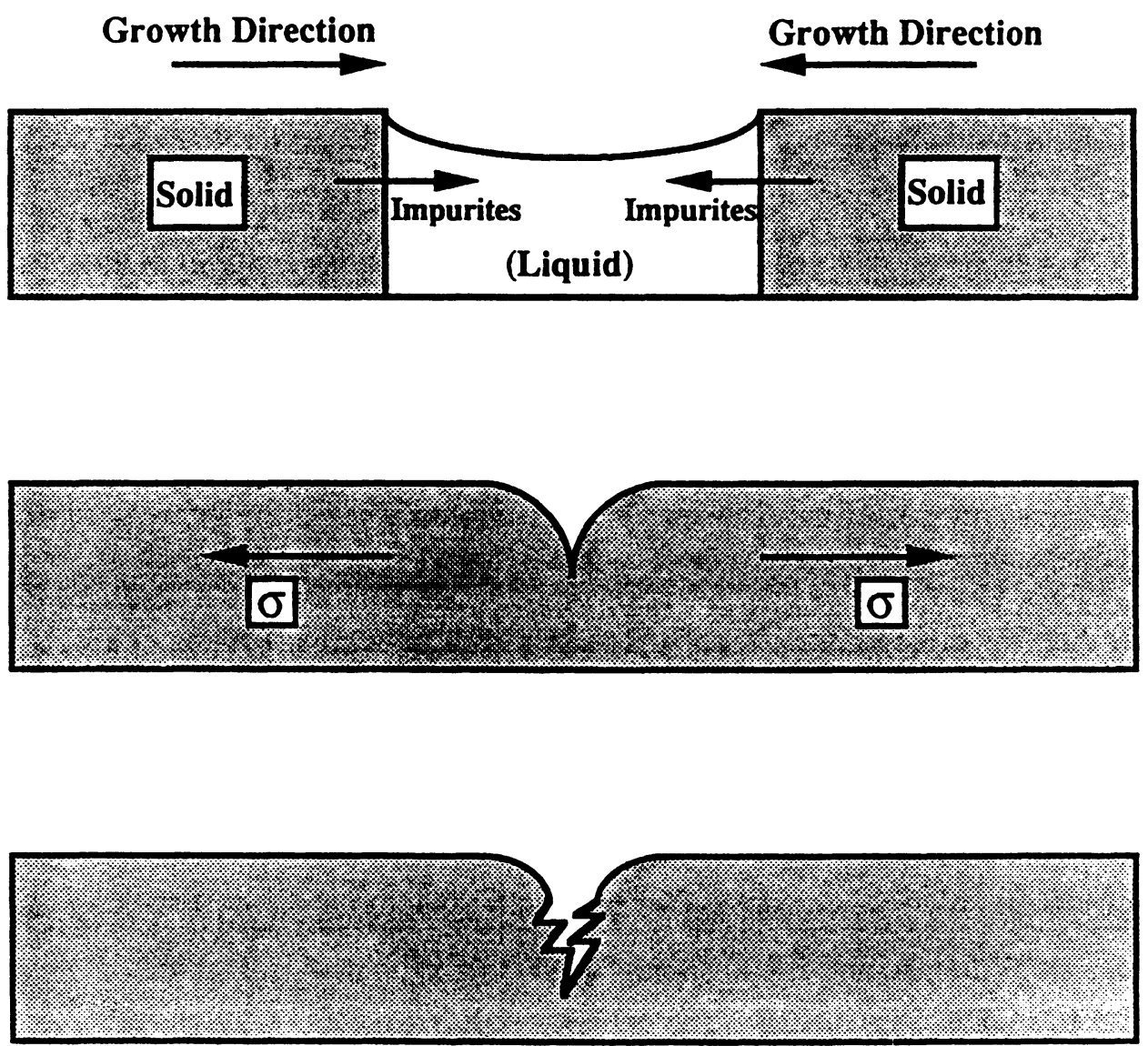

Figure 7 Three-stage schematic drawing showing the steps leading to denting/cracking on Galfan $(\mathrm{t} 1<\mathrm{t} 2<\mathrm{t} 3)$ [Bluni, Marder, 1993]. 
of the zinc coatings, based on the shear analysis, is given by Pak and Meshii (1990b).

\section{SUMMARY}

The texture of the zinc coating influences the cracking behaviour during deformation, due to the anisotropic deformation behaviour.

It has been stated in theoretical consideration, that cracks, caused by cleavage, take place when the c-axis is parallel to the tensile axis. If the c-axis is normal to the compression axis neither twinning nor cleavage occurs.

According to the forming test there are various parts of tensile, compression and sliding stresses that operate simultaneous in the zinc coating. Differences in the elongation or flow behaviour of substrate and coating may induce shear stresses in the interface. Alloying elements in zinc usually change the mechanical properties and therefore the deformation behaviour of zinc. Therefore, the cracking behaviour of zinc coatings has to be considered as complex.

The texture determines primarily the deformation and cracking behaviour in zinc coatings. If no plastic deformation is possible in the zinc because of an unfavourable texture, cracks have to accommodate substrate deformation. Such unfavourable textures have shown to be prism textures where the basal plane is tilted $90^{\circ}$ to the sheet surface, but also the $\{10 \overline{1} 1\}$ texture with their basal planes tilted $65^{\circ}$ to sheet surface. In coatings with favourable textures plastic flow occurs, which leads to texture changes.

The grain size effect on cracking behaviour is of secondary order when compared to texture, but larger grains tend to promote cracking.

Especially in the hot dip zinc coatings, if extensive cracking has been found, this is not only due to a basal plane texture, which has been observed in several cases, but also to the intermetallic layer, which nucleates cracks during the deformation. The intensity of cracking increases with an increasing thickness of the intermetallic layer.

In general, if the same textures in zinc occurred, similar results of deformation behaviour were found despite diffferent test methods.

\section{References}

Allegra, L., Hart, R. G. and Townsend, H. E. (1983). Intergranular Zinc Embrittlement and Its Inhibition by Phosphorus In 55 pct. Al-Zn-Coated Sheet Steel., Metallurgical Transactions A, Vol. 14A, 3, pp. $401-411$.

Aoki, I., Horita, T. and Herai, T. (1982). Formability and Application of Galvanized Sheet Steels. Technological Impact of Surfaces: Relationship to Forming, Welding and Painting, In Materials/ Metalworking Technology Conf. Proc., Metals Park, Ohio, ASM, p. 165.

Bablik, H. (1950). Galvanizing (Hot Dip). 3rd Edition, Spon Ltd., London, p. 204.

Bell, R. L. and Cahn, R. W. (1957). Proc. Roy. Soc. Vol. [A], 239, p. 494.

Bluni, S. T. and Marder, A. R. (1993). Mechanical Behaviour of Zinc Coating. In The Physical Metallurgy of Zinc Coated Steel, A. R. Marder ed., TMS, Warrendale, PA, pp. 99-109.

Cameron, D. I., Harvey, G. J. and Ormay, M: K. (1965). The Spangle of Galvanized Iron. The Journal of the Australian Institute of Metals, Vol. 10, No. 3, 8, pp. 255-264.

Chang, S. (1990). Characterization and development of Zn-Fe alloyed coating layer. In Zinc-Based Steel Coating Systems, Metallurgy and Performance. G. Krauss and D. K. Matlock eds., TMS, Warrendale, PA, pp. 319-330.

Clark, R. and Craig, G. B. (1952). Progress Metal Physics. Vol. 3, p. 115.

Davis, K. G. and Teghtsoonian, E. (1963). Trans. Met. Soc. A.I.M.E. Vol. 227, p. 762.

Deits, S. H. (1990). Mechanisms of Coating Failures During Deep Drawing of Coated Sheet Steels. Master of Science Thesis, MT-SRC-090-008, Colorado School of Mines, Golden, Colorado 80401. Deits, S. H. and Matlock, D. K. (1990). Formability of Coated Sheet Steels: An Analysis of Surface 
Damage Mechanisms. In Zinc-Based Steel Coating Systems, Metallurgy and Performance. G. Krauss and D. K. Matlock eds., TMS, Warrendale, PA, pp. 297-318.

Deruyttere, A. and Greenough, G. B. (1955-1956). Institute of Metals, Vol. 84, pp. 337-345.

Drewien, C. A., Ackland, D. and Marder, A. R. (1990). Rapid Heat Treatment of EZA Coatings. In Zinc-Based Steel Coating Systems, Metallurgy and Performance. G. Krauss and D. K. Matlock eds., TMS, Warrendale, PA, pp. 31-42.

Dreulle, N., Frappa, A., Limare, A., Piessen, P. and Sokolowski, R. (1985). Influence de l'aluminium dans la protection par le zinc de l'acier contre la corrosion atmosphérique. Matériaux et Techniques, 73, 2-3, pp. 77-83.

Foct, J., lost, A. and Reumont, G. (1993). Mechanical Behaviour of Zinc Coating. In The Physical Metallurgy of Zinc Coated Steel, A. R. Marder ed., TMS, Warrendale, PA, pp. 21-30.

Foct, J., Reumont, G. and Perrot, P. (1993). The Morphology of Zinc Coatings. In The Physical Metallurgy of Zinc Coated Steel. A. R. Marder ed., TMS, Warrendale, PA, pp. 1-9.

Gilman, J. J. (1955). Trans. Amer. Inst. of Min. (Metall.) Engrs., Vol. 203, pp. 1252-1254.

Gronostajski, J. Z. and Ali, W. J. (1988). Analysis of Formability of Coated Steel Sheet at Complex Strain Paths. In Proc. of the 15th. Biennial Congress of the IDDRG, Dearborn, Michigan, pp. 4347.

Gupta, I., Cline, R. S. and Patil, R. S. (1984). Effect of Iron-Zinc Alloy Layer on the Mechanical Properties and Formability of Hot-Dip Galvanized Steels. S.A.E. Technical Paper No. 840284.

Habraken, L. (1978). Le zinc et ses applications. Première partie. Métallurgie XVIII, 3/4, pp. 8186.

Haughton, M. A. (1953). Proc. 2nd Int. Conf. on Hot-Dip Galfanizing. Düsseldorf, ed. by Zinc Development Assoc., Oxford, p. 59.

Hisamoto, J., Ikeda, K., Yamamura, N. and Satoh, H. (1990). The Effect of coating hardness on the Peeling-Off Behaviour of Electrogalvanized Steel Sheets and some Aspects to Their Press Formability. In Zinc-Based Steel Coating Systems, Metallurgy and Performance. G. Krauss and D. K. Matlock eds., TMS, Warrendale, PA, pp. 331-340.

Hylton, T. A., and Wenzloff, G. J., Van Tyne, C. J. and Matlock, D. K. (1992). The Importance of Microstructure, Surface Roughness, and Properties on the Frictional Behaviour of Electrogalvanized Sheet Steels. In Proc. of Galvatech '92, ed. by Centre de Recherches Métallurgiques, Amsterdam, The Netherlands. Verlag Stahleisen, Düsseldorf, Germany, pp. 166-170.

Hylton, T. A., Van Tyne, C. J. and Matlock, D. K. (1993). Frictional Behavior of Electrogalvanized Sheet Steels. Reprinted from: Sheet Metal and Stamping Symposium (SP-944), Internat. Congress and Exposition, Detroit, Michigan. 3, pp. 241-253.

Hughes, M. L. (1951). Proc. lst Int. Conf. on Hot-Dip Galfanizing. Copenhagen, ed. by Zinc Development Assoc., Oxford, p. 31.

Kubaschewski, O. (1986). Binary Alloy Phase Diagrams, Editor-in-Chief: Massalski, T. B. American Society for Metals, p. 1128.

Lin, C. S., Chiou, W. A. and Meshii, M. (1993). Effect of Phosphorus Content in Base-Steel on the Formation of Alloy Layer of Hot-Dip Coated Steel Sheets. In The Physical Metallurgy of Zinc Coated Steel, A. R. Marder ed., TMS, Warrendale, PA, pp. 31-40.

Lindborg, U. (1975). Observations on the Growth of Whisker Crystals from Zinc Electroplate, Metall. Trans. A, Vol. 6A, pp. 1581-1586.

Makimatilla, S. and Ranta-Eskola, A. (1984). Behaviour of Galvanized Coatings During Forming. In Proc. of 13th Bienn. Congr. of the IDDRG, Melbourne, Australia, pp. 293-304.

Marder, A. R. (1990). Microstructural characterization of zinc coatings. In Zinc-Based Steel Coating Systems, Metallurgy and Performance. G. Krauss and D. K. Matlock eds., TMS, Warrendale, PA, pp. 55-82.

Mei, Z., and Morris, Jr., J. W. (1993). Cracking of Textured Zinc Coating During Forming Process. In The Physical Metallurgy of Zinc Coated Steel, A. R. Marder ed., TMS, Warrendale, PA, pp. 11-20.

Pak, S.-W., Lin, Y. and Meshii, M. (1989). Effect in the Crystallographic Orientation on Behaviour Commercial Zinc Coatings. TMS Fall Meeting, Indianapolis, Indiana, 10.

Pak, S.-W. and Meshii, M. (1990a). Structure - Mechanical Property Relation. In Zinc Electrogalvanized Coatings. in Zinc-Based Steel Coating Systems, Metallurgy and Performance. G. Krauss and D. K. Matlock eds., TMS, Warrendale, PA, pp. 357-369.

Pak, S.-W. and Meshii, M. (1990b). Analysis of Cracking Behavior of Electrogalvanized Coatings. In Zinc-Based Steel Coating Systems, Metallurgy and Performance. G. Krauss and D. K. Matlock eds., TMS, Warrendale, PA, pp. 341-355.

Partridge, P. G. (1965). Phil. Mag. Vol. 12, p. 1043. 
Partridge, P. G. (1967). The crystallography and deformation modes of hexagonal close-packed metals. Metallurgical Reviews, Review 118, pp. 169-194.

Rangarajan, V. (1989). Effects of Coating Properties on the Formability of Coated Sheet Steels. Ph.D. Dissertation, MT-SRC-089-043, Colorado School of Mines, Golden, Colorado 80401.

Rangarajan, V., Giallourakis, N. M., Matlock, D. K. and Krauss, G. (1989). The Effect of Texture and Microstructure on Deformation of Zinc Coatings. J. Mater. Shaping Technol. No. 4, 6, pp. 217-227.

Rangarajan, V., Matlock, D. K. and Krauss, G. (1990). The Effects of Coating Properties on the Frictional Response of Zinc-Coated Sheet Steels. In Zinc-Based Steel Coating Systems, Metallurgy and Performance. G. Krauss and D. K. Matlock eds., TMS, Warrendale, PA, pp. 263-280.

Rangarajan, V., Natalie, C. A., Matlock, D. K. and Krauss, G. (1990). Deformation Behaviour of Hot Dip Galvanized Coatings in Complex Sheet Metal Forming. J. Mater. Shaping Technol., No. 2, 8, pp. 101-105.

Shaffer, S. J., Morris, J. W. Jr. and Wenk, H.-R. (1990). Texture Characterization and its Applications on Zinc Electrogalvanized Steels. In Zinc-Based Steel Coating Systems, Metallurgy and Performance. G. Krauss and D. K. Matlock eds., TMS, Warrendale, PA, pp. 129-140.

Shaffer, S. J., Nojima, W. E., Skarpelos, P. N. and Morris, J. W. Jr. (1990). Research on the Metallurgical Determinants of Formability in Electrogalvanized Sheet. In Zinc-Based Steel Coating Systems, Metallurgy and Performance. G. Krauss and D. K. Matlock eds., TMS, Warrendale, PA, pp. 251261.

Shi, M. F., Smith, G. M., Moore, M. and Meuleman, D. J. (1990). Galvannealed Coating Optimized for Coating Adhesion Through Dies. In Zinc-Based Steel Coating Systems, Metallurgy and Performation. G. Krauss and D. K. Matlock eds., TMS, Warrendale, PA, pp. 387-389.

Stevenson, R. (1985). Formability of Galvanized Steels-Revisited. S.A.E. Technical Paper No. 850276.

Takechi, H., Matsuo, M., Kawasaki, K. and Tamura, T. (1981). Textures and Properties of Metallic Coatings on Sheet Steels. In Proc. of ICOTOM 6, Tokyo, Japan, pp. 209-222.

Tang, N.-Y. and Adams, G. R. (1993). Studies on the inhibition of alloy formation in hot-dip galvanized coatings. In The Physical Metallurgy of Zinc Coated Steel, A. R. Marder ed., TMS, Warrendale, PA, pp. 41-54.

Townsend, H. E., Allegra, L., Dutton, R. J. and Kriner, S. A. (1986). Hot-dip coated sheet steels - A review. Material Performance. Vol. 25, 8, pp. 36-46.

Vlad, C.M., Dahms, M. and Bunge, H. J. (1988). ODF Analysis of Texture of Galfan-and Galvanized Hot Dipped Coatings of Low Carbon Steel Sheets. In Proc. of ICOTOM 8, J. S. Kallend and G. Gottstein eds., The Metallurgical Society, pp. 855-860.

Warnecke, W., Bode, R., Kothe, R. and Meyer, L. (1990). Modern Hot Dip Coated Sheet Steel Processing, Coating Characteristics and Fabricating Properties. In Zinc-Based Steel Coating Systems, Metallurgy and Performance. G. Krauss and D. K. Matlock eds., TMS, Warrendale, PA, pp. 317.

Wenzloff, G. J., Van Tyne, C. J. and Matlock, D. K. (1993). The importance of microstructure and properties on the formability of eletrogalvanized sheet steels. In The Physical Metallurgy of Zinc Coated Steel, A. R. Marder ed., TMS, Warrendale, PA, pp. 275-293. 